\title{
Toward food sovereignty and self-sufficiency in Latin America and the Caribbean: opportunities for agricultural complementarity
}

\author{
Hacia una soberanía y autosuficiencia alimentaria en América \\ Latina y el Caribe: oportunidades de complementariedad agrícola \\ Pedro Cango ${ }^{1,2}$ (D) , Jesús Ramos-Martín ${ }^{3,4}$ (D), Fander Falconí ${ }^{5}$ (D) \\ ${ }^{1}$ Grupo de Población y Ambiente, Universidad Regional Amazónica Ikiam, Tena, Ecuador. E-mail: pedro.cango@ikiam.edu.ec \\ ¿Universidad Complutense de Madrid, Madrid, Spain. \\ ${ }^{3}$ Departament d'Economia i d'Història Econòmica, Universitat Autònoma de Barcelona (UAB), Barcelona, Spain. \\ E-mail: jesus.ramos@uab.cat \\ ${ }^{4}$ Institut de Ciència i Tecnologia Ambientals, Universitat Autònoma de Barcelona (UAB), Barcelona, Spain. \\ ${ }^{5}$ Departamento de Desarrollo, Ambiente y Territorio, Facultad Latinoamericana de Ciencias Sociales (FLACSO), Quito, Ecuador. \\ E-mail: ffalconi@flacso.edu.ec
}

How to cite: Cango, P., Ramos-Martín, J., \& Falconí, F. (2023). Toward food sovereignty and self-sufficiency in Latin America and the Caribbean: opportunities for agricultural complementarity. Revista de Economia e Sociologia Rural, 61(1), e251291. https://doi.org/10.1590/1806-9479.2021.251291

\begin{abstract}
Food self-sufficiency is a relevant political issue in many countries, developed and developing, particularly to satisfy the internal nutritional needs of the population and face situations in which the prices of basic products are unstable or when a country faces an external shock. Improving resilience involves strengthening local rural communities to meet demand with domestic production. The member countries of Latin America and the Caribbean (LCN) produce enough food to sustain their population and to be one of the world's largest food exporters. From the theoretical discussion and using data from FAO, the research shows that there is a potential to improve food sovereignty and to define food and agricultural policies through agricultural complementarity among the LCN countries. Diverting part of the current trade with third parties to intraregional trade, for products in which the region has a comparative advantage, would mean that LCN countries could save up to 2.7 billion dollars per year, that is, $6.8 \%$ of total imports of food in 2018 , avoiding the outflow of foreign currency and promoting greater economic integration between countries.
\end{abstract}

Keywords: food sovereignty, self-sufficiency, trade, LCN, complementarity, economic integration.

Resumen: La autosuficiencia alimentaria es un tema político relevante en muchos países, desarrollados y en desarrollo, particularmente para satisfacer las necesidades nutricionales internas de la población y enfrentar situaciones en las que los precios de los productos básicos son inestables o cuando un país enfrenta un shock externo. Mejorar la resiliencia implica fortalecer las comunidades rurales locales para satisfacer la demanda con producción interna. Los países miembros de América Latina y el Caribe (LCN) producen suficientes alimentos para sustentar a su población y para ser uno de los mayores exportadores mundiales de alimentos. A partir de la discusión teórica y usando datos de la FAO, la investigación muestra que, existe un potencial para mejorar la soberanía alimentaria y para definir las políticas alimentarias y agrícolas a través de la complementariedad agrícola entre los países de LCN. Desviar parte del comercio actual con terceros al comercio intrarregional, para productos en los que la región tiene una ventaja comparativa, representaría que los países de LCN podrían ahorrar hasta 2.700 millones de dólares al año, es decir, 6.8\% del total de las importaciones de alimentos en 2018, evitando la salida de divisas y promoviendo una mayor integración económica entre los países.

Palabras clave: soberanía alimentaria, autosuficiencia, comercio, LCN, complementariedad, integración económica. 


\section{Introduction}

Human beings have several needs that need to be satisfied to live in full, understanding this as the state in which individuals can develop and pursue effectively their capabilities (Malinowski, 1939, 1970). In this sense, food plays an important role as it acts as the satisfier of a basic need, nourishment (Maslow, 1943). This implies that an inadequate supply of food not only threatens the integrity of the individual, but also the sustainability of societies.

For this reason, societies articulate as an entity made up of institutions that work to satisfy their own needs (Malinowski, 1939, 1970). At the international level, common political, legal, economic, or social institutions are created through regional integration processes between countries (Hix, 2001).

From the perspective of nourishment, regional integration may become an opportunity to build common strategies that encourage, through agricultural complementarity, food selfsufficiency. That is, the situation in which food needs are covered with domestic production (Food and Agriculture Organization of the United Nations, 2002), something the world is far from attaining nowadays (Kinnunen et al., 2020). In this case, achieving political influence is only possible if there are studies like ours that show the potentiality of regional cooperation and integration towards regional self-sufficiency.

This move implies a change in the food production system of Latin American and Caribbean countries (LCN), which until now have prioritized production for exports instead of that of internal supply (Pengue, 2009). This trend has implied a gradual loss in food self-sufficiency and an increase in vulnerability to external factors, for instance, to international prices.

Therefore, agricultural complementarity, defined as the contribution each member country has in the production of food that is needed to achieve self-sufficiency of the bloc, becomes an instrument of cooperation and integration. Among the benefits of this cooperation one can list: a) improvement in transport and communications through regional investment in infrastructure; b) mutual assistance in the case of production problems - for example draughts, plagues, etc.; c) promotion of regional economies of scale and d) improvements in food security (Hubbard et al., 1992). Another benefit, although modest, is the reduction in the currency outflow that escapes the region.

Currently, many successful experiences of common strategies exist, promoted by supranational entities, and oriented to food self-sufficiency. This is the case of the European Union, which has achieved that goal through the Common Agricultural Policy (Guinea, 2013). The EU produces more food than it consumes, avoiding in this way a supply-side problem in recent decades (Candel et al., 2014).

For these reasons, similar strategies for the region would strengthen its food sovereignty, improve the efficiency in the use of natural resources, and would increase economic profitability. This would also help to avoid developed countries' food policy affecting developing ones'. Something that is far too familiar nowadays (Brooks, 2014).

However, the design of these strategies requires reliable information regarding agricultural products trade, between LCN countries, and with the rest of the world. This information needs to be available not only in monetary terms but also in nutritional terms. Only in this way, one can get a wider vision of the role international trade plays on the nutritional security of countries (D'Odorico et al., 2014).

Following that, the main objective of this article is to examine the opportunity for agricultural complementarity that LCN has, to achieve food self-sufficiency as a bloc. To do this, after the introduction, section 2 presents a discussion of the relevant literature related to self-sufficiency and food security. Later, in section 3, a description of materials and methods is presented. In the 
fourth section, the results are analyzed according to the methodology presented for challenges in the region, food self-sufficiency and opportunities for agricultural complementarity. Then in section 5, the policy implications are discussed and finally, in section 6, the conclusions are presented.

\section{Literature review}

Pastorino (2020) points out that the term "food security" is not recent. It can be considered an objective (i.e., to solve the problem of hunger and nutrition in the world), an end or goal (for agrarian law it could mean a search for safe food) or a paradigm or a new way of thinking about food from the political, economic, social, and cultural perspectives.

The Rome Declaration on World Food Security, during the 1996 World Food Summit, defined the concept by saying that there is "food and nutritional security" when all people have physical, social and economic access to safe food at all times, the consumption of which is sufficient in terms of quantity and quality to satisfy their food needs and preferences and is supported by a framework of sanitation, health services and adequate care that allow them to lead an active and healthy life (Food and Agriculture Organization of the United Nations, 1996).

At the 1996 World Food Summit, the proposal was to halve the number of undernourished people by 2015. In 2015, the UN approved the 2030 Agenda for Sustainable Development with 17 goals (SDGs). One of them calls for ending hunger, achieving food security and improved nutrition, and promoting sustainable agriculture by 2030.

However, hunger levels remain stable. With data from 2017 at the global level, there were 821 million undernourished people. By the end of 2020, it is estimated that the Covid-19 pandemic could have caused an increase of 130 million in the number of people affected by chronic hunger worldwide (Hidalgo \& Sorondo, 2020).

In 2018, LCN recorded that the number of undernourished people increased for the third consecutive year, reaching 39.3 million, that is, $6.1 \%$ of the population. In ten countries, $20 \%$ of the poorest children suffer three times more from chronic malnutrition. Indigenous populations are more food insecure than non-indigenous and rural populations more than urban (Food and Agriculture Organization of the United Nations, 2018b).

Hochedez (2021) reviews the term "food justice" and points out that it is not the traditional framework for analyzing food problems in Latin America, since it is preferred to speak of food insecurity and food sovereignty or sustainable development. He argues that the term food justice implies a real change in the way food inequalities are resolved. However, the Latin American approach highlights two different ways of looking at food justice: accessibility and the right to food.

Accessibility is a classic first way of looking at food justice as good access to safe and quality food. This is traditionally analyzed from the point of view of consumers. It also leads to consider access to resources to produce food as part of accessibility to food. This approach also highlights the processes of connection and disconnection between consumers and producers, between rural and urban areas.

The second approach analyzes food justice in terms of the law. This approach brings food to the context of democracies, including the State's responsibility for food. In addition, food is part of citizenship and a way of exercising our citizenship. At the individual level, the approach of "right to" food justice faces several challenges in Latin America, such as the right to land and access to land, the right to access to food, the right to the city (through urban agriculture initiatives, for example), labor rights in agriculture, in agri-food systems, or the distribution sector. 
However, Clendenning et al. (2016) argue that food sovereignty is based more on human rights than similar concepts of food security and, to a lesser extent, food justice. Food sovereignty emphasizes the recovery of the land, food, livelihoods, and identities of people with a lack of food security through their direct participation in the design and implementation of food systems. Food security is a social condition that emphasizes knowing where the next meal will come from and does not address the production, distribution, or control of access to food (Hossfeld et al., 2018). Food justice is a progressive social movement that seeks to address injustices based on race and class (Hossfeld et al., 2018). The food justice movement also develops strategies to "work around and outside" the broader food system to provide access to food for marginalized groups (Clendenning et al., 2016).

The distinctions between these concepts influence who participates in which area and who benefits. For example, in urban areas, food sovereignty can be seen in urban agriculture, home and community gardens, and direct-to-consumer markets such as farmers markets and community-supported agriculture (Clendenning et al., 2016).

Ferranti et al. (2019) make a compendium of a collection of articles in a book on food security and sustainability, which allows an adequate understanding of this relationship. The different approaches and methods used make it possible to understand the different dimensions of the concept of food security.

The global food system is key to sustaining humanity (Rockström et al., 2020). In addition, it is the main emitter of greenhouse gases and is the central cause of loss of biodiversity, destruction of terrestrial ecosystems, consumption of fresh water and pollution of waterways due to the excessive use of nitrogen and phosphorus. Faced with this, they propose safe limits for the development of the world food system, and three essential actions: 1) a change towards healthy diets, 2) an increase in agricultural productivity and a transition towards regenerative production, and 3) reduce the food waste.

Work on food security, sovereignty, or self-sufficiency has adopted usually a national and single product point of view. Amid (2007), for instance, analyzes the case of wheat in Iran from a market and price perspective; Anderson \& Strutt (2014) analyze how economic growth and demographic transition in China is making the country more dependent on food imports, modeling its evolution until 2030. Cuesta et al. (2013) argue that public expenditure in Bolivia is not effective in reducing food insecurity. Farrow et al. (2005), on the other hand, show how spatial heterogeneity may play an important role as a determinant of the lack of access to food products in Ecuador, a problem particularly important in the central mountain range. Hassan et al. (2000), adopting a food security-like perspective, analyze the case of wheat and cotton in Sudan, reaching the conclusion that is the interest of Sudan to encourage cotton so that currency is obtained that can be used to import wheat. Giampietro et al. (2014), applying an innovative biophysical approach in the line of that presented in this study, analyze two national case studies, self-sufficiency of wheat in India and total food self-sufficiency in Mauritius islands.

Only a few studies analyze the productive possibilities and availability of food at the regional level. Since the work of O'Hagan (1976), according to which most of the countries had food selfsufficiency, things have changed drastically and many countries and regions have worsened in this respect. Despite this fact, there is a lack of studies with a regional scope.

Among those few studies, one could highlight that of Blackie (1990), where self-sufficiency of corn in Eastern and Southern Africa is analyzed. This is one of the first studies making explicit the potential of trade diversion for one product, complementing in this way the previous work of Koester (1986). 
Using both available surveys and FAO food balances, Asfaw (2008) checks the availability of fruits and vegetables for human consumption in Latin America and the Caribbean. The conclusion is reached that the region shows low levels of consumption despite the availability of the products in the region is high.

The focus of the region as a food exporter comes with impacts attached. Ceddia et al. (2013) analyze the intensification of agriculture in South America, concluding that the region would face a "Jevons" Paradox" like situation; that is, efficiency improvements would not lead to lowering the use of the resource (land) but the opposite would be true. More efficient techniques of production will use more land to export more. In the case of intensification of agriculture, at the expense of more deforestation occurring.

A group of authors takes on the effects of trade and trade policies of regional blocs upon access to food products in developing countries. Brooks (2014) shows how policies implemented by OECD countries have harmed developing countries, especially through import tariffs and production subsidies at home, which lead to surplus exports, generating their example of trade diversion. Candel et al. (2014) use a similar approach to analyze the EU's Common Agricultural Policy. They stress that food security is at the roots of the very existence of the EU, having as a result, an increase in the food surplus. On the other hand, Rask \& Rask (2011) show how development at the world level is changing the diet everywhere, towards more meat products that imply a double energy conversion, increasing in this way cereal and oilseeds demand more than proportionally. This fact imposes further pressure upon natural resources and increases the risk of future food provision.

Having in mind all these precedents, our focus here is the situation of Latin America and the Caribbean. Altieri (1992) pointed out that the agricultural model found in Latin America is not based on distributed land. Land reform is still a pending issue in most countries. As a consequence, heterogeneity of levels of productivity is one of the characteristics of the model and this implies environmental impacts attached. The region is rich not only in terms of biodiversity but also in terms of cultural diversity, with important ethnoecological knowledge.

Other authors have a more positive view of the model of agro-exports in southern countries. Bindraban \& Rabbinge (2012) say, based on Food and Agriculture Organization of the United Nations (2011), that there are no problems to feed the population at the world level in the next four or five decades. They base their optimism on productivity gains obtained through the introduction of multiple crops and land use systems, agroecological practices, changes in the diet, and the use of new inputs from biological origin.

Siegel \& Bastos (2020) carry out a critical evaluation of the incorporation of the Sustainable Development Goals in the national agendas of agri-food governance in three countries: Brazil, Paraguay and Uruguay. The nominal incorporation of the SDG agenda does not imply implementation, since it involves more complex institutional changes that depend on the power relations of the actors, resources, capacities and previous experiences of civil society and governments.

The current paper goes beyond the concept of food security defined at the World Food Summit organized by Food and Agriculture Organization of the United Nations (1996), which included economic access to food (through purchasing power and markets). We rather fall into the concept of food sufficiency that analyzes the relation between local availability of resources and its domestic demand, more oriented to the concept of food sovereignty (Altieri, 2009). The paper does not pretend to make a thorough review of the topic; the interested reader can refer to Chaifetz \& Jagger (2014), where the authors conduct a full revision of the concept of food sovereignty for the last 40 years. 
The idea of improving food sufficiency in a region that has huge potential if economic integration was promoted, makes even more sense in the current context of the high volatility of prices, and unequal exchange relations in all its dimensions. In this context, the region faces the great challenge imposed by deteriorating terms of trade (Prebish, 1950, 1959; Singer, 1950), unequal ecological exchange (Samaniego et al., 2017; Vallejo, 2010), and caloric unequal exchange (Falconí et al., 2017; Ramos-Martín et al., 2017).

The international insertion of Latin America and the Caribbean in international trade has been limited to play as a supplier of food and raw materials. This only perpetuates international dependency and asymmetries in international trade. This is coherent with modern interpretations of comparative advantages (Krugman \& Obstfeld, 2003), which state that countries would import those goods that are either difficult or expensive to produce internally and export products in which they have an advantage in terms of costs.

These trends, far from benefiting countries exporting commodities, deepen an unjust international division of labor. Countries producing commodities compete with each other to sell their products in the same market, by lowering costs and prices in a so-called "race-to-thebottom". As all of them follow this path, the consequence is an intensification of the exploitation of natural resources, a worsening of current unequal exchange, and a better-off situation for central economies that get the resources they need at ever-lower prices (Schaffartzik et al., 2014).

Traditionally, the extraction of natural resources has been one of the ways to express this unequal economic exchange: selling cheap commodities and buying expensive capital goods. Along with it, there is a sub valuation of social and environmental impacts (Bunker, 1984; Alier, 1992).

\section{Material and Methods}

The research seeks to examine the opportunities for agricultural complementarity for the countries of Latin America and the Caribbean. The methodology used is subdivided into three parts: main challenges for the region in terms of food production, food self-sufficiency, and opportunities for agricultural complementarity.

\subsection{Main challenges for the region in terms of food production}

Using data from FAO (Food and Agriculture Organization of the United Nations, 2020e), we analyze the growth of the agricultural frontier between 1961 and 2018 and the deterioration of forests between 1991 and 2018. This is a comparison made between LCN, the world average, and the rest of the regions of the world, using the World Bank classification: East Asia \& Pacific (EAS), Europe \& Central Asia (ECS), Middle East \& North Africa (MEA), North America (NAC), South Asia (SAS), Sub-Saharan Africa (SSF), and World (WLD). To test the statistical significance in the average growth in the period for both indicators for iregions and LCN, the Kruskall-Wallis test was used. However, when the test showed significant differences in the distributions and was rejected the null hypothesis, we used Dunn's nonparametric pairwise multiple-comparison test (Dinno, 2015).

Then, using data from FAO (Food and Agriculture Organization of the United Nations, 2020a), differences in yields are analyzed for nine groups of products for LCN, according to the groups found at the food balances published by FAO. Grouping of the nine groups of products was done relying on the availability of data, according to FAO classification (Food and Agriculture Organization of the United Nations, 2020b). For this indicator, as in the previous analysis, we 
have compared the average productivity in the period 1961-2019 between the i region and LCN, according to the product group.

Furthermore, using data from UNCTAD (2019) we have calculated exports by technology intensity for the countries of Latin America and the Caribbean. For this purpose, detailed classification by technology was used (Lall, 2000).

\subsection{Food self-sufficiency}

To calculate food self-sufficiency, we have used detailed trade matrices from 1986 through 2018 (Food and Agriculture Organization of the United Nations, 2020d), as well as national food balances (old methodology for series between 1961 and 2013, and new food balances for series between 2014 and 2018) available in FAOSTAT (Food and Agriculture Organization of the United Nations, 2017, 2021). In this case, FAO data allows using 19 product groups instead of 9, as we did for agricultural land. LCN countries are considered as a region, as we are only interested in the region as a bloc and the relationship with the rest of the world.

We have used 19 product groups corresponding to vegetal and animal products, as classified by FAO. These products are cereals - excluding beer; starchy roots; sugar crops; sugar \& sweeteners; pulses; tree nuts; oil crops; vegetable oils; vegetables; fruits - excluding wine; stimulants; spices; alcoholic beverages; miscellaneous; meat; offals; animal fats; milk - excluding butter, and eggs; aquatic products, other; and fish, seafood. However, when analyzing intra-regional trade, we excluded: a) aquatic products, other; and b) fish, seafood, because there is no data available. For these 19 product groups, we analyze food self-sufficiency as shown in the following lines.

To obtain the trade flow from LCN countries with the rest of the world, we calculated, for each country member, the volume consumed by country (LCN) and the volume imported by country of origin (rest of the world). The following indicator shows self-sufficiency (SS) (Falconí et al., 2017; Ramos-Martín et al., 2017).

$S S_{r t}=\left(1-\frac{\sum M_{r k j t}}{\sum C_{r k t}}\right) * 100$

Where:

$M=$ Total imports; $r=$ product group; $k=$ country of the $\mathrm{LCN} ; t=$ year; $j=$ no LCN countries. In this case, the imports (product group $r$ ) of the country $k$ from country $j$ in year $t(M)$; consumption (product group $r$ ) of the country $k$ in year $t(C) ; \forall k \in L C N$ and $\forall j \notin L C N$.

A value of self-sufficiency equal or greater to 100 for this indicator shows whether the region is self-sufficient for that product group or not. On the other hand, values below 100 indicate the region only partially supplies its domestic consumption with domestic production and therefore is not one hundred per cent self-sufficient. In the case there is domestic consumption but not domestic production, the indicator gets a value of zero.

Likewise, we analyze the relationship between self-sufficiency and nutrition. In this analysis, we consider the indicator food supply (kcal/person/day) provided by (Food and Agriculture Organization of the United Nations, 2017, 2021).

\subsection{Complementarity opportunities}

Using FAO's detailed trade matrix (Food and Agriculture Organization of the United Nations, 2020d), we analyze the opportunities for agricultural complementarity of the 19 product groups (described in the previous section) between LCN countries. To avoid heterogeneity between 
the groups of products in the food balance used in this study, we have disaggregated all 296 products, whose definitions can be found in FAO's definitions and standards (Food and Agriculture Organization of the United Nations, 2020b).

$$
O C_{r t}=\sum X(\text { Ton })_{i k j t}-\sum M(\text { Ton })_{i k j t} \text { if }\left\{\begin{array}{l}
X \geq M, O C \text { strong } \\
X<M, O \text { OC weak } \\
X=0, \text { OC null }
\end{array}\right.
$$

Where:

$O C_{r t}$ represents the opportunities for agricultural complementarity of the product group $r$ in year $t ; x(T o n)_{i k j t}$ represents the exports, measured in tons, of product $i$, by country $k$ to country $j$ in year $t, M(T o n)_{i k j t}$ represents the imports, measured in tons, of product $i$, by country $k$ to country $j$ in year $t$. $\forall k \in L C N$ and $\forall j \notin L C N$.

In the case of products that show opportunities for agricultural complementarity, we assume that the countries in the region substitute imports from the rest of the world with imports from other countries within the region that would, otherwise, be exported to the rest of the world. With this assumption, we can compute the approximate monetary value (constant 2015 USD) of food imports and exports. To estimate exports and imports in monetary terms (constant prices 2015), we adjusted to value-added deflator by country for agriculture, silviculture, and fishing, available in FAOSTAT (Food and Agriculture Organization of the United Nations, 2020c).

Then, the regional value is obtained, as follows:

$$
X C_{t}= \begin{cases}\sum X(U S \$)_{i k j t}-\sum M(\text { Ton })_{i k j t} * \bar{p} x_{i k j t}+\sum M(T o n)_{i k j t} * \bar{p} x_{i k k t} ; & \text { If } X \geq M \\ \sum X(U S \$)_{i k j t}-\sum X(T o n)_{i k j t} * \bar{p} x_{i k j t}+\sum X(T o n)_{i k j t} * \bar{p} x_{i k k t} ; & \text { If } X<M\end{cases}
$$

Where:

$M C_{t}$ total imports of LCN with complementarity (constant $2015 \mathrm{US} \$$ ) in year $t ; X C_{t}$ total exports of LCN with complementarity (constant 2015 US\$) in year $t ; \bar{p} m_{i k k t}$ is the average import price for product $i$, country $k$, from LCN (countryk) in year $t ; \bar{p} m_{i k j t}$ is the average import price for product $i$, country $k$, from country $j$ in year $t ; \bar{p} x_{i k j t}$ is the average export price for product $i$, country $k$, to country $j$ in year $t ; \forall k \in L C N$ y $\forall j \notin L C N$.

In the case of imports of product $i$ for which the region has a surplus, we consider that the region reduces its exports to the rest of the world by the total of imports from the rest of the world. The assumption is made that country $k$ (member of LCN) covers its deficit in product $i$ at the average price of its imports from the region (country $k$ ) in year $t$. Likewise, for product $i$ for which the region has a deficit, we assume that the region promotes complementarity in total exports to the rest of the world, at the average price of product $i$ that country $k$ imports from the region (country $k$ ) in year $t$. Whereas, the remaining deficit of each product $i$ in country $k$ would be covered by maintaining imports from the rest of the world at the average price of its imports from the rest of the world (country $\mathrm{J}$ ) in year $t$.

On the other hand, the value of exports with complementarity $(X C)$ is estimated considering that this policy reduces food exports to the rest of the world and increases at the regional level. For product $i$ with a regional surplus, we find the difference between the value of exports to the rest of the world in constant dollars of 2015 and the monetary difference that results from replacing the imports from the rest of the world at the average price of product $i$ that country $k$ exports to the rest of the world in year $t$ for the average price of the same product that country k exports intra-regionally. Similarly, for products with a food deficit, the difference 
between the value of exports (constant dollars of 2015) and the monetary difference resulting from replacing the exports to the rest of the world at the average price of product $i$ exported by country $k$ by the average price of the same country and product exported within the region.

However, the missing prices of country $k$ and product $i$ (imports as intra- or extra-regional exports) were imputed with the average value (regional or rest of the world) in year $t$. It should be noted that the use of averages corresponds to one of the univariate imputation techniques (van Buuren \& Groothuis-Oudshoorn, 2011).

\section{Results}

\subsection{Main challenges of the region}

Three main challenges for food production in the region are discussed in this section: arable land availability, low production yields, and global insertion in food trade.

According to Food and Agriculture Organization of the United Nations (2018a), between 2012 and 2050, on a global scale, crop areas could increase by $23 \%$ and the size of the herd of animals by $46 \%$. This increase in land use is worrying when it comes to walking towards the sustainability of the planet. However, not all regions have the same degree of vulnerability.

Data from Food and Agriculture Organization of the United Nations (2020a), show that between 1962 and 2018 Europe \& Central Asia and North America had a negative average annual growth in agricultural land. On the other hand, in South Asia, Sub-Saharan Africa, and the World, agricultural land increased about 0.1\%; this yearly increase was $0.3 \%$ in East Asia \& the Pacific, $0.4 \%$ in Latin America and the Caribbean, and $0.5 \%$ in the Middle East \& North Africa. Using Dunn's z-test we can see that only East Asia \& Pacific and the Middle East \& North Africa have average annual growth rates statistically equal to LCN (see Figure 1).

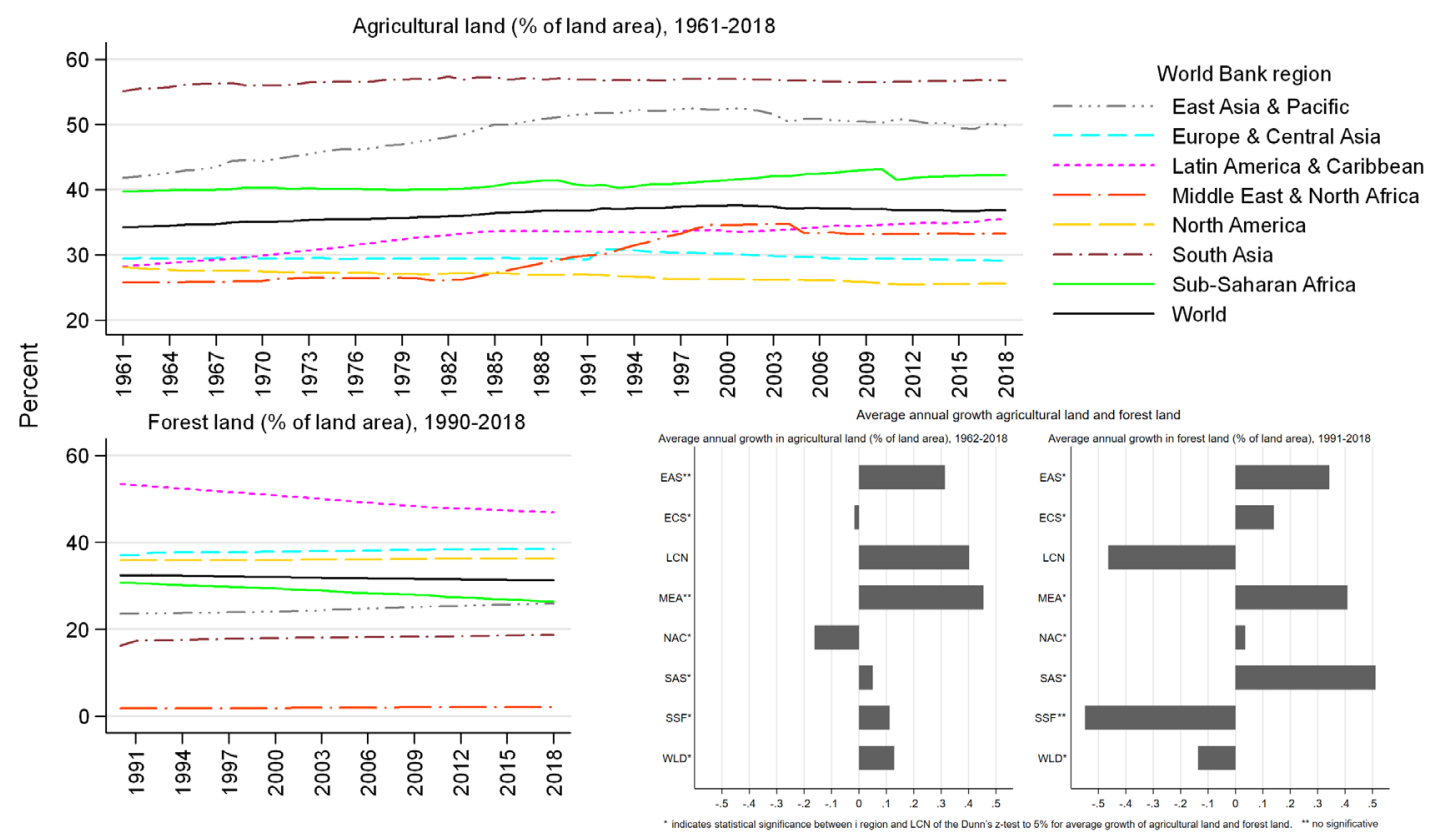

Figure 1. Agricultural land and forest land by region, 1961-2018. Source: (Food and Agriculture Organization of the United Nations, 2020e). 
This increase in agricultural land in LCN, as in SSF and the World, was at the expense of forest area, which diminished (as a \% of the land area). Forest land (as \% of land area) decreased between 1991 and 2018 in LCN and SSF. The rate of annual decrease in forest land was $0.46 \%$ for LCN and $0.56 \%$ for SSF. This decrease, using Dunn's test, turned out to be statistically the same. This dichotomy is statistically different from the average annual reduction of the world (0.1\%) and the other regions such as North America, which increased on average by $0.04 \%$, Europe \& Central Asia by $0.1 \%$, East Asia \& Pacific by $0.3 \%$, Middle East \& North Africa $0.4 \%$ and South Asia 0.5\%.

According to Ferreira et al. (2016) between 1961 and 2010, 19 Latin American countries presented a positive variation in total factor productivity (TFP) in agriculture, which has contributed to a growth in production and technical development. Likewise, Reis et al. (2020) show that between 1991 and 2012, the area and labor presented positive effects on the production of 18 LCN countries. In this context between 1962 and 2018, food production increased in the region. Vegetables grew by $2.9 \%$ per year, and animal products grew by $2.8 \%$ per year (Food and Agriculture Organization of the United Nations, 2017, 2021). That is, agricultural production kept the path of population growth. Currently, LCN represents $14 \%$ of the world's agricultural production and $23 \%$ of agricultural and fish commodities exports (Organisation for Economic Co-operation and Development, 2019).

This increase in production and in agricultural land, which helps to explain how the agricultural frontier is still expanding in the region threatening particular ecosystems like the Amazon basin, is coupled with low productivity. According to the World Bank (2021), the labor productivity of workers in the agriculture, forestry, and fishing sector in LCN was 7,347 USD (constant 2010) in 2018. This represents just $47.8 \%$ of the productivity of an agricultural worker from Europe \& Central Asia and a mere $8.5 \%$ of the productivity of a North American farmer.

According to the FAOSTAT database (Food and Agriculture Organization of the United Nations, 2020a), yields of the different product groups were, in the region, as follows: cereals (excluding beer) $1.3 \mathrm{t} / \mathrm{ha}$, starchy roots $9.8 \mathrm{t} / \mathrm{ha}$, sugar crops $49.3 \mathrm{t} / \mathrm{ha}$, pulses $0.6 \mathrm{t} / \mathrm{ha}$, tree nuts $14.8 \mathrm{t} / \mathrm{ha}$, vegetables $6.6 \mathrm{t}$ t/ha, fruits (excluding wine) $13.0 \mathrm{t} / \mathrm{ha}$, and stimulants $0.5 \mathrm{t} / \mathrm{ha}$ (see Figure $2 \mathrm{a}-\mathrm{i}$ ). Productivity of LCN in 1961 was higher than the average for the world and regions such as EAS, MEA, SAS, and SSF, in at least 6 of the 9 product groups. However, in that same year, the productivity of product groups in the region was lower than the results obtained in NAC, except for tree nuts. Concerning ECS, LCN only exceeded productivity for sugar crops, tree nuts, and fruits (excluding wine). The productivity for oil crops was the same in the three regions.

On the other hand, using Dunn's test, the average productivity by product group for the period 1961 and 2019 of the $i$ regions and Latin America and the Caribbean is compared (see Figure 2j). We can observe that North America and East Asia \& Pacific had significantly higher productivity than LCN in cereals (excluding beer) and oil crops, while it was the same when comparing with Europe \& Central Asia, except for oil crops, where LCN has higher productivity. The productivity of starchy roots, pulses, and vegetables was also higher in EAS, ECS, MEA, and NAC than in LCN.

LCN had higher average productivity than the other regions in sugar crops, tree nuts, and fruits (excluding wine), except for sugar crops, where it turned out to be statistically equal to that of NAC and SSF. In the case of fruits (excluding wine), Dunn's test shows that NAC has higher productivity. In the case of stimulants, ECS, MEA, NAC, and SAS have higher productivity than LCN and are equal to EAS. At the same time, LCN outperforms SSF in all product groups, except for sugar crops, as already mentioned above. 

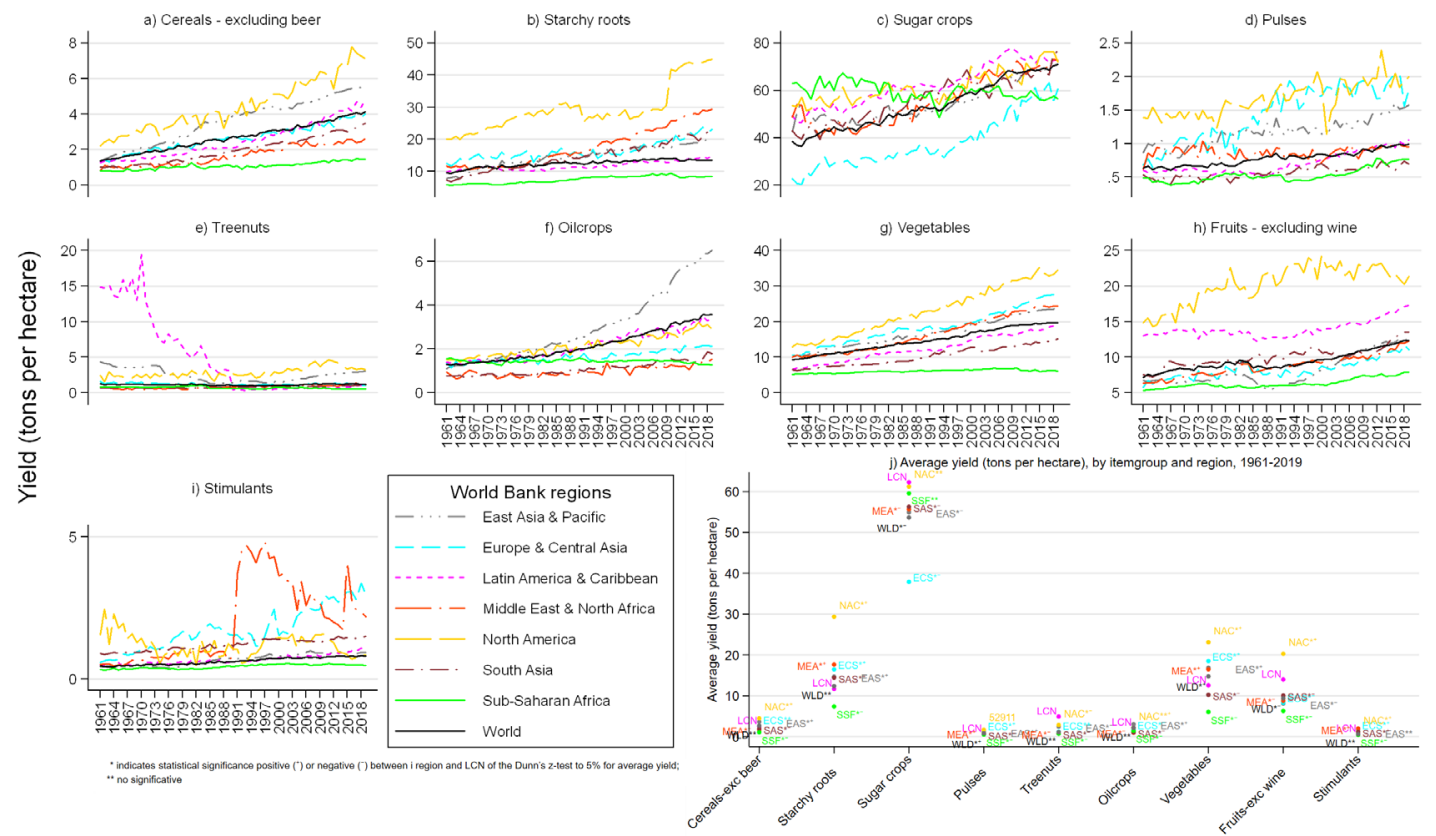

Figure 2. Yields (tons per hectare) by region and product groups, 1961-2019.Source: (Food and Agriculture Organization of the United Nations, 2020a).

In addition to low productivity, the economy of LCN countries indeed has a great dependence on exports of raw materials and food products. Primary exports of commodities represented $43.3 \%$ of total exports in monetary terms in the year 1995, and they went down to $32.3 \%$ in 2018 (UNCTAD, 2019).

\subsection{Food self-sufficiency and nutrition in LCN countries}

Using the indicator of self-sufficiency presented in Section 3 we see that LCN is self-sufficient as a bloc. Between 1986 and 2018, it maintained a level of 80\% self-sufficiency in all product groups but spices and animal fats (See Table 1). However, the level of self-sufficiency has been reducing over time for all product groups, but sugar crops, vegetal oils, Alcoholic beverages, miscellaneous, and milk - excluding butter. This is an alarming outcome, especially if we consider that many regions in the world will face soon diminishing rates for food self-sufficiency (Beltran-Peña et al., 2020).

This aggregate result of self-sufficiency at the continental level does not hold when we go down to the level of nations, where there is heterogeneity within countries, although a common trend is that all countries of LCN have insufficiency of some products. This result opens the door to gains from agricultural complementarity between countries, which is crucial because, as Clapp (2017) mentioned, self-sufficiency in just a few products is not enough to eradicate hunger and malnutrition. Conventional economics tells us that if a product is cheaper in international markets than it is domestically, a country should import that product. Under this reductionist logic, based exclusively on monetary variables, we can omit fundamental aspects of the issue. One of them is the existing link between food self-sufficiency and nutrition, due to the cultural diversity (genetic and gastronomic) of a country. In this way, importing food products may have direct impacts in terms of losing genetic diversity and the local food culture, which could lead to changes in the traditional diet, associated with the spread of malnutrition or overweight. 
Apparent consumption, measured as calorie intake per person per day, increased in almost all LCN countries in the period 1961-2018. The only exception being Venezuela, where calorie intake went from 2,147 kcal/person/day in 1961 to 2,121 kcal/person/day in 2018 (Food and Agriculture Organization of the United Nations, 2017, 2021).

Along with the increase in calorie intake, one can see a change in the diet of the population (see Figure 3), which would follow the so-called Bennet's Law (Bennet, 1941). According to Bennet, carbohydrate intake would be reduced as income per capita grows, and protein-rich products such as meat would increase its consumption.

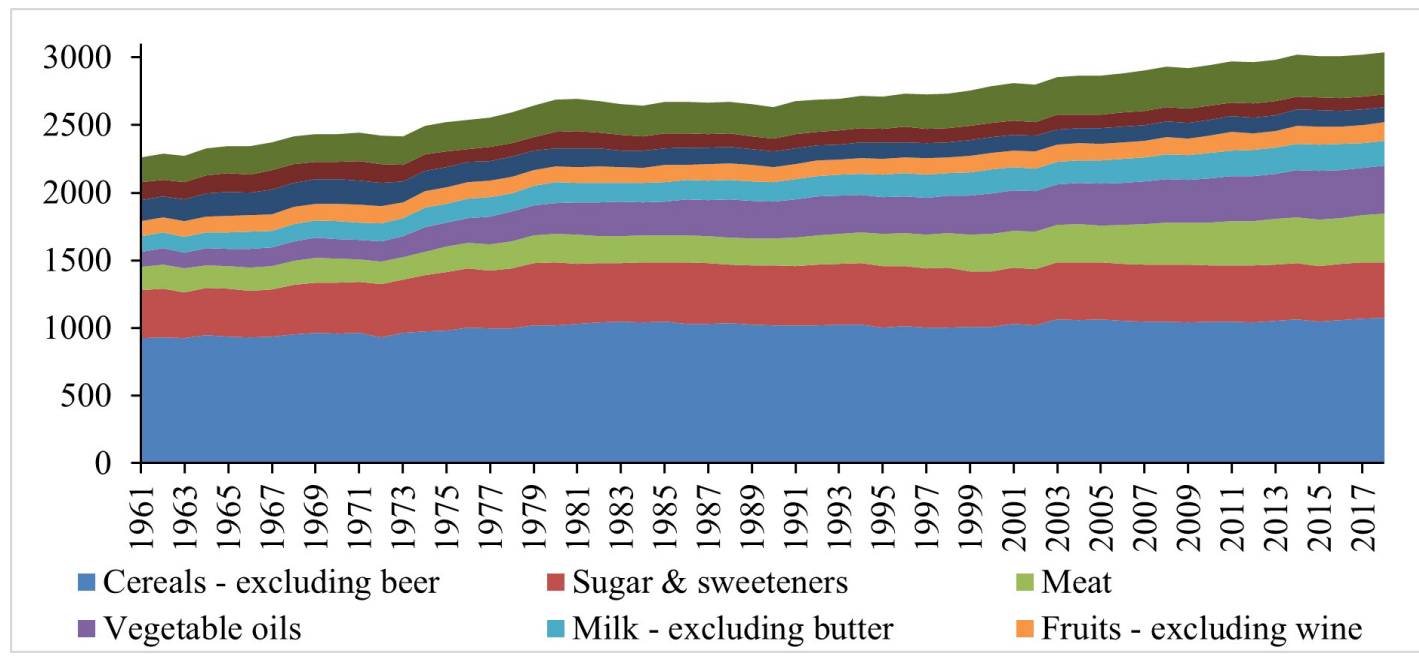

Figure 3: Origin of the energy (kcal) of apparent consumption, LCN (1961-2018). *Includes Sugar Crops, tree nuts, oil crops, vegetables, stimulants, spices, alcoholic beverages, and miscellaneous, offals, animal fats, eggs, fish seafood.Source: (Food and Agriculture Organization of the United Nations, 2017, 2021).

Meat calorie intake went up at a yearly growth rate of $1.3 \%$, vegetal oils at $2.1 \%$, milk (excluding butter) at $0.9 \%$, fruits at $0.4 \%$, while cereals (excluding beer) and starchy roots grew at $0.3 \%$ and $-0.5 \%$ respectively, in the period analyzed.

\subsection{Opportunities for complementarity}

To look at the opportunities for complementarity between LCN countries, we need to see imports and exports from and to the rest of the world. This is what is presented in Table 2 with data for 2018. The bloc imported 74.3 million tons from the rest of the world. Only four product groups accounted for $86.9 \%$ (cereals excluding beer, with 65.5\%; oil crops, 13.2\%; sugar and sweeteners, 4.1\%; and meat, 4.0\%). On the other hand, the bloc exported 235.5 million tons of food to the rest of the world. Again, four product groups represent $84.5 \%$ (oil crops, 38.2\%; cereals excluding beer, 22.3\%; fruits, excluding wine, 12.8\%; and sugar and sweeteners, 11.2\%).

Table 3 shows the opportunities for complementarity between LCN countries. The cells in grey, show surplus exports for each member country and by product group, to third countries in 2018. The cells in white show the deficit. In that year, Antigua and Barbuda, Bahamas and Saint Kitts and Nevis showed a deficit in all product groups. While, Barbados, Saint Lucia, Saint Vincent and the Grenadines, Suriname, and Trinidad and Tobago showed surplus only in one product group. Similarly, Cuba, El Salvador, and Guyana showed a surplus to two product groups. The countries with fewer product groups with the deficit are Argentina and Brazil. 


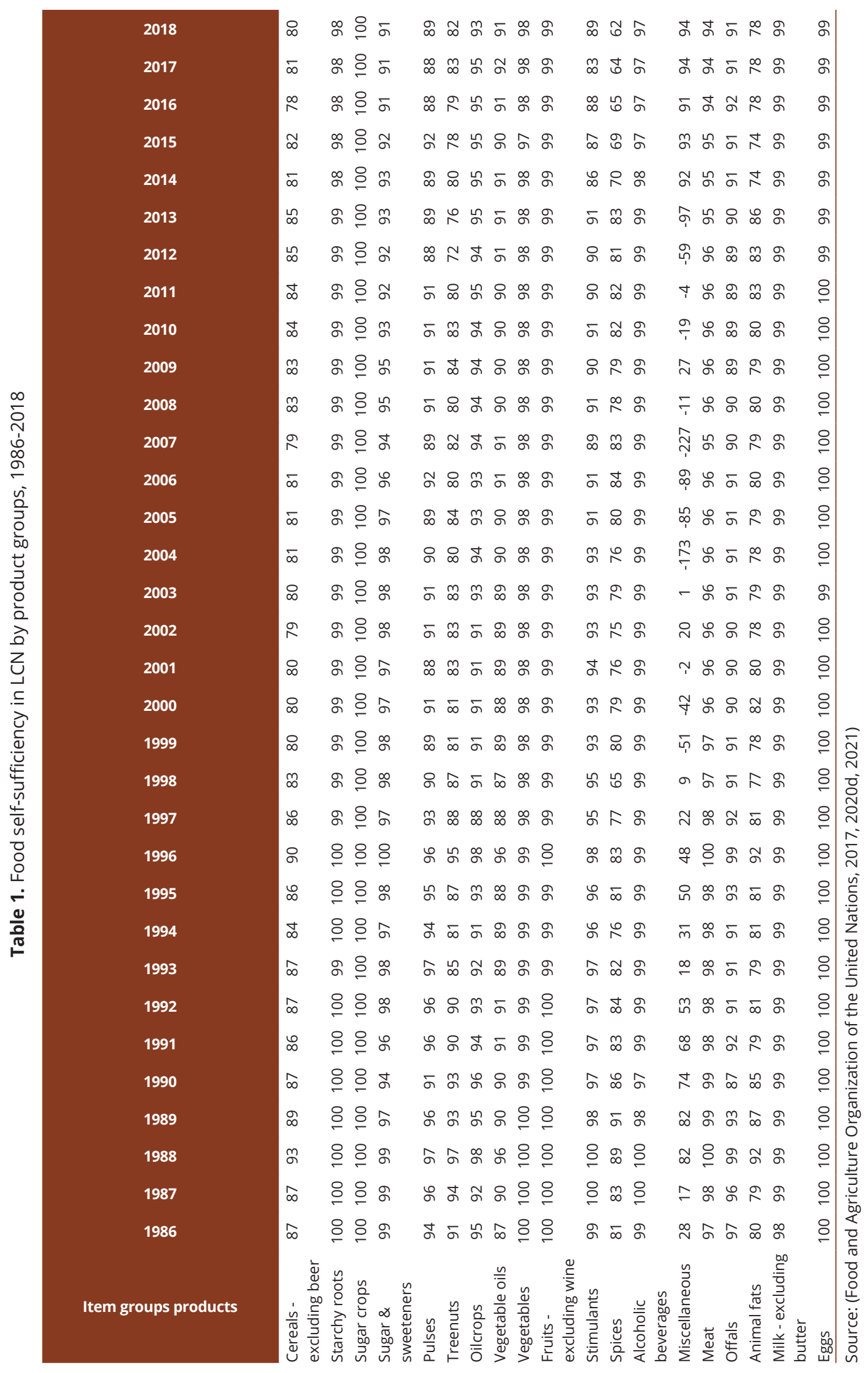


On the other hand, the aggregate surplus exceeded 161.2 million tons. The region shows commercial surplus for all product groups but starchy roots, pulses, miscellaneous, animal fats, milk - excluding butter, and eggs, where the proportion of the exports to imports were, respectively, $20.9 \%, 78.8 \%, 66.5 \%, 29.8 \%, 35.0 \%$, and $27.2 \%$. Replacing imports from outside the bloc with current exports to outside the bloc would imply reducing exports amounting to 72.2 million tons in 2018. In other words, to satisfy the consumption level of the LCN countries due to the deficit of some products, the region will have to keep importing 2.8\% of the food imported in 2018 from the rest of the world, which means that exports towards the rest of the world would decrease by $30.7 \%$.

Table 2. Volume of imports and exports of LCN from and to the rest of the world, in thousands of tons, 2018

$\begin{array}{lcc} & \text { Imports } & \text { Exports } \\ \text { Cereals - Excluding Beer } & 48,640.7 & 52,529.4 \\ \text { Starchy Roots } & 1,074.7 & 224.4 \\ \text { Sugar Crops } & 0.03 & 0.1 \\ \text { Sugar \& Sweeteners } & 3,074.2 & 26,379.9 \\ \text { Pulses } & 828.7 & 653.1 \\ \text { Treenuts } & 101.8 & 252.8 \\ \text { Oilcrops } & 9,840.8 & 89,890.2 \\ \text { Vegetable Oils } & 1,982.6 & 7,557.4 \\ \text { Vegetables } & 1,030.4 & 9,848.1 \\ \text { Fruits - Excluding Wine } & 1,123.2 & 30,188.3 \\ \text { Stimulants } & 373.4 & 4,398.3 \\ \text { Spices } & 91.2 & 222.0 \\ \text { Alcoholic Beverages } & 1,213.3 & 4,971.6 \\ \text { Miscellaneous } & 29.1 & 19.4 \\ \text { Meat } & 2,995.4 & 7,355.4 \\ \text { Offals } & 292.8 & 469.6 \\ \text { Animal fats } & 523.7 & 155.9 \\ \text { Milk - Excluding Butter } & 995.2 & 348.7 \\ \text { Eggs } & 67.6 & 18.4\end{array}$

Source: (Food and Agriculture Organization of the United Nations, 2020d).

Supplementary material shows the opportunities for agricultural complementarity between LCN member countries in 2018, broken down by all the 296 products included in the 19 product groups presented in Table 3. In this annex, LCN showed a surplus for 161 out of 296 products. The five countries with the highest number of surplus products are Brazil (126), Mexico (106), Peru (89), Argentina (82), and Chile (80). Size matters and Brazil had a surplus of 137.6 million tons, followed by Argentina with 34.6 million tons, Guyana 14.8 million tons, Ecuador 5.9 million tons, and Costa Rica 4.0 million tons. Similarly, the five products with the highest regional surplus were soybeans, with 81.0 million tons, followed by sugar raw centrifugal, with 20.2 million tons, bananas 14.6 million tons, maize 12.5 million tons, and wheat 8.4 million tons.

A policy of regional complementarity among the LCN countries would result in a modest monetary surplus. For example, in 2018, net exports in constant 2015 dollars reached 106.6 billion dollars, while this balance would be 99.5 billion dollars with the integration proposal. However, by replacing imports from the rest of the world with products that would otherwise be exported to the rest of the world, food imports would cost the region 8.1 billion dollars more (constant 2015 US \$).

These results show that, despite the proximity between countries in the region, given the historical trade prices, it is cheaper to import from the rest of the world than to import from 
the same region. This is the result of the challenges the region experiences mentioned above: low labor productivity, low yields, and lack of proper policies, such as subsidies found in the US, Canada, or the EU. As an example, in the case of Mexico, 12 out of 19 product groups have lower international prices than those offered, as average, by the region. Meanwhile, the inflow of currency for exporting countries would increase by 1.0 billion dollars. This is in response to the fact that exports to the rest of the world have a higher price than exports to LCN member countries.

On the other hand, under the hypothesis that the region could prioritize complementarity for products that are cheaper to acquire within the region than from the rest of the world, the savings would be approximately 2.7 billion dollars, that is, $6.8 \%$ of the total of imports from the rest of the world. Meanwhile, the monetary value of exports would decrease by approximately 1.3 billion. Using the Kruskall Wallis test we can also see that the average food balances with and without complementarity between 1986 and 2018 are statistically equal.

The apparent low economic benefits that a policy of complementarity would imply are offset by the decrease in environmental impacts that are favored by the reduction in food transport between regions and the outflows of foreign currency. Likewise, as pointed out by Krapohl (2019), regional integration would produce effects of size and stability that would help attract investment flows from the rest of the world. It would even be a policy that fosters higher levels of competitiveness for the region in the global market.

\section{Policy implications}

The results presented above indicate that, despite the challenges LCN countries face, there exists a potential gain from food production and trade complementarity between them. The countries, as a bloc, produce enough food to feed their population and be net exporters to the rest of the world.

To exploit the advantages provided by available arable land and soil, and climatic conditions without compromising their natural resources base, LCN countries need to confront some of the challenges mentioned. This is of special relevance as the region shows a pattern of deindustrialization in recent years (Cango et al., 2018).

They need to increase yields, which are much lower than those of third-country partners. They also need to implement sound agricultural policies that strengthen the sector. This can be achieved with the implementation of national-scale technical assistance programs, which are too project-based these days. Given the lack of financial strength that prevents countries to implement subsidies policies like in the USA or the EU, governments could work also on price guarantees to producers, at least for staples. But a better alternative would be to involve public procurement systems that exist in most of the countries for other kinds of goods. Many of the countries have implemented school food plans, where children are given breakfast and sometimes also lunch at the school. This is a good opportunity for establishing price guarantees to producers, instead of relying on big corporations. The extra income could be used by peasants to improve their technology and inputs, raising yields.

These interventions would have a larger impact if coordinated between LCN countries. Most of the countries face the same challenges, including lack of access to cheap credit, another reason to ask for the integration of policies. This integration could not only include productivityoriented measures but could address the whole production cycle: from the technification of production and post-harvest processing to infrastructure and logistics and the coordination of trade policies. These measures would help climbing the value-added ladder, bringing more currency to the region. 


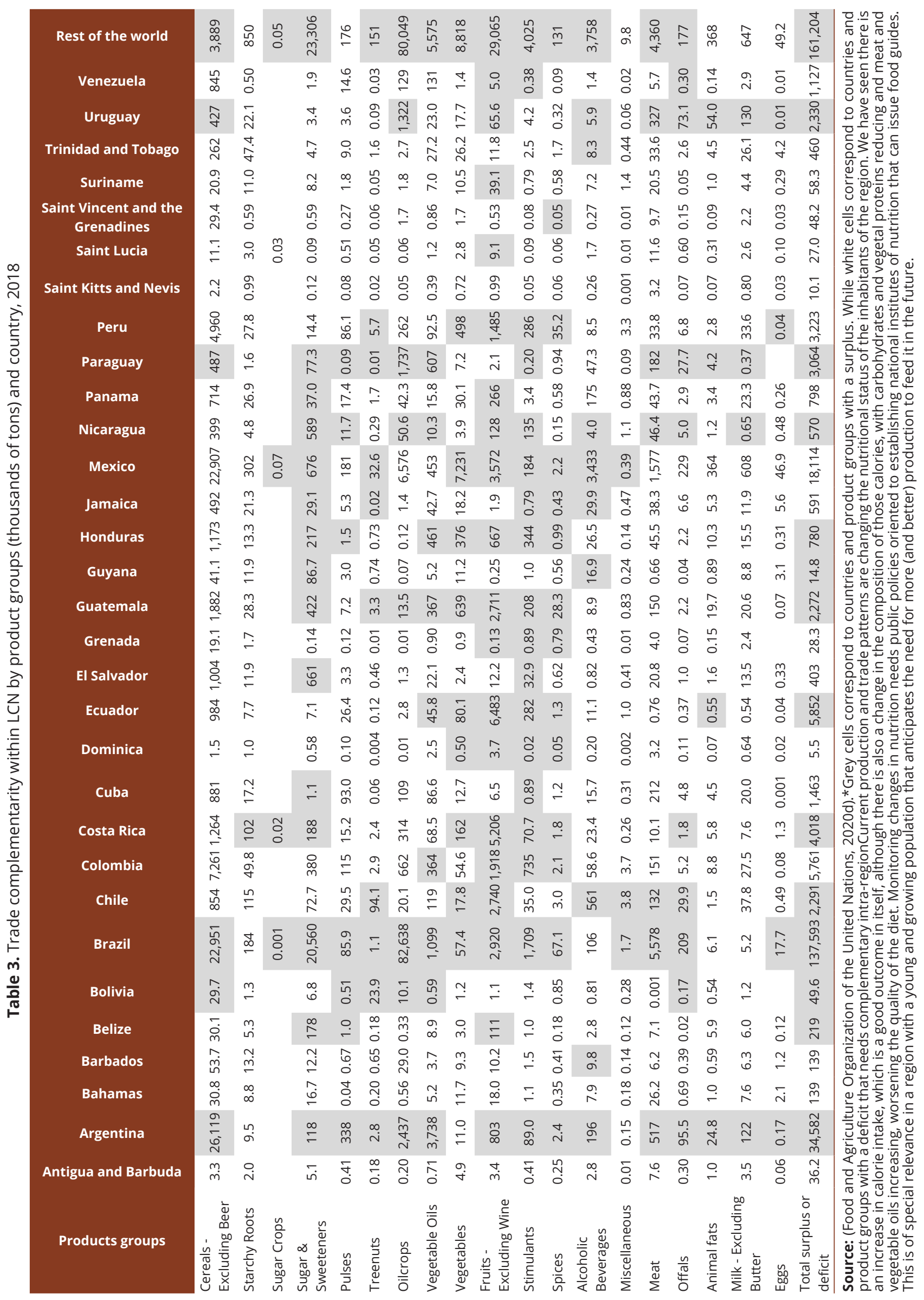


Coordination, integration, and joint policies are needed to overcome challenges that are too difficult or too expensive when tackled individually, it is a question of economies of scale, as the EU exemplifies. Common policies, although slower in their implementation, tend to result in more stable economies, as a large fraction of trade would be intra-regional trade. This is of particular importance for a region of currency-hungry countries which tend to overexploit their natural resources to obtain the hard currency they need for their imports.

We know that the savings presented in this research are modest, but would imply a step forward towards economic integration, which could lead, as it did in the EU, to future common policies in other related areas such as product certification and quality standards, supra-national logistic and transport projects and hopefully some kind of integration also of commercialization and trade policies.

Finally, as shown in the article, to re-direct trade to the region, we believe that the region should initially promote a policy of agricultural complementarity for products whose domestic prices are lower than those of the rest of the world. At the same time, agricultural complementarity agreements should be promoted between the countries, with synchronization of regional macroeconomic and agricultural policy, and strong support from governments to local producers to strengthen value chains.

\section{Conclusions}

This research has contributed to the debate on food self-sufficiency in LCN countries and has shown there is room to advance food and agricultural complementarity. Regional selfsufficiency and complementarity are fundamental elements to guarantee that the inhabitants of the region have their caloric needs covered.

The region is self-sufficient, as a bloc, in 17 out of 19 product groups. Trade diversion would reduce the region's vulnerability to exogenous factors such as price volatility, natural hazards, and external trade policies from the rest of the world. In turn, this move would strengthen the agri-food sector in the region, allowing for more robust internal markets and integration, and highlighting the need for common trade policies.

It is true, though, that the challenges of low yields and labor productivity persist, with developed regions such as North America or Europe \& Central Asia offering lower prices for certain products (in part thanks to their policy of subsidies). This is why regional integration should go beyond trade diversion, aiming at common policies from production to commercialization.

Despite all the challenges ahead, complementarity would still save $6.8 \%$ of total imports from the rest of the world, meaning that 2.7 billion a year would remain in the region, inducing extra economic activity, and therefore profits, wages, and taxes.

Other positive outcomes can come from this policy, such as the reduction in currency outflows, transport needs, and therefore energy use and $\mathrm{CO}_{2}$ emissions; the strengthening of value chains in the region; an increase in job opportunities; an impulse to rural development; and a reduction in poverty among others.

This is why, in our view, the region can only benefit from harmonizing policies that would allow for exploiting this complementarity between countries for the benefit of the whole region. We are aware, though, that this requires solid integration agreements between nations, which harmonize macroeconomic policies in countries with limited autonomy, countries with restricted access to food and countries with limited agricultural production, generated mainly by the high levels of social inequality in the region. We hope the debate opens up with more research and discussion soon. 


\section{Acknowledgements}

The authors would like to thank the editor and the anonymous referees for providing relevant comments that improved the paper. The second author acknowledges support from the Project HAR201676814-C2-1-P AEI/FEDER, UE, Ministerio de Economía, Industria y Competitividad, Spain.

\section{References}

Alier, J. M. (1992). De la economía ecológica al ecologismo popular. Barcelona: Icaria Editorial.

Altieri, M. A. (1992). Sustainable agricultural development in Latin America: exploring the possibilities. Agriculture, Ecosystems \& Environment, 39(1-2), 1-21.

Altieri, M. A. (2009). Agroecology, smallfarms, and food sovereignty. Monthly Review, 61(3), 102-113.

Amid, J. (2007). The dilemma of cheap food and self-sufficiency: the case of wheat in Iran. Food Policy, 32(4), 537-552.

Anderson, K., \& Strutt, A. (2014). Food security policy options for China: lessons from other countries. Food Policy, 49(1), 50-58.

Asfaw, A. (2008). Fruits and vegetables availability for human consumption in Latin American and Caribbean countries: patterns and determinants. Food Policy, 33(5), 444-454.

Beltran-Peña, A., Rosa, L., \& D'Odorico, P. (2020). Global food self-sufficiency in the 21st century under sustainable intensification of agriculture. Environmental Research Letters, 15, 1-11. http://dx.doi.org/10.1088/1748-9326/ab9388

Bennett, M. K. (1941). International contrasts in food consumption. Geographical Review, 31(3), 365-376. https://doi.org/10.2307/210172

Bindraban, P. S., \& Rabbinge, R. (2012). Megatrends in agriculture - views for discontinuities in past and future developments. Global Food Security, 1(2), 99-105.

Blackie, M. J. (1990). Maize, food self-sufficiency and policy in East and Southern Africa. Food Policy, 15(5), 383-394.

Brooks, J. (2014). Policy coherence and food security: the effects of OECD countries' agricultural policies. Food Policy, 44, 88-94.

Bunker, S. G. (1984). Modes of extraction, unequal exchange, and the progressive underdevelopment of an extreme periphery: the Brazilian Amazon, 1600-1980. American Journal of Sociology, 89(5), 1017-1064.

Candel, J. J. L., Breeman, G. E., Stiller, S. J., \& Termeer, C. J. A. M. (2014). Disentangling the consensus frame of food security: the case of the EU Common Agricultural Policy reform debate. Food Policy, 44, 47-58.

Cango, P., Ramos-Martín, J., \& Falconí, F. (2018). The regional political economy of knowledge and environment. In E. Vivares (Ed.), Regionalism, development and the post-commodities boom in South America (pp. 197-215). Cham: Springer. https://doi.org/10.1007/978-3-319-62551-5_9

Ceddia, M. G., Sedlacek, S., Bardsley, N. O., \& Gomez-y-Paloma, S. (2013). Sustainable agricultural intensification or Jevons Paradox? The role of public governance in tropical South America. Global Environmental Change, 23, 1052-1063.

Chaifetz, A., \& Jagger, P. (2014). 40 years of dialogue on food sovereignty: a review and a look ahead. Global Food Security, 3(2), 85-91.

Clapp, J. (2017). Food self-sufficiency: making sense of it, and when it makes sense. Food Policy, 66, 88-96. http://dx.doi.org/10.1016/j.foodpol.2016.12.001 
Clendenning, J., Dressler, W., \& Richards, C. (2016). Food justice or food sovereignty? Understanding the rise of urban food movements in the USA. Agriculture and Human Values, 33(1), 165177. http://dx.doi.org/10.1007/s10460-015-9625-8

Cuesta, J., Edmeades, S., \& Madrigal, L. (2013). Food security and public agricultural spending in Bolivia: Putting money where your mouth is? Food Policy, 40, 1-13.

D’Odorico, P., Carr, J., Laio, F., Ridolfi, L., \& Vandoni, S. (2014). Feeding humanity through global food trade. Earth's Future, 2, 458-469.

Dinno, A. (2015). Nonparametric pairwise multiple comparisons in independent groups using Dunn's test. The Stata Journal, 15(1), 292-300.

Falconí, F., Ramos-Martin, J., \& Cango, P. (2017). Caloric unequal exchange in Latin America and the Caribbean. Ecological Economics, 134, 140-149. http://dx.doi.org/10.1016/j. ecolecon.2017.01.009

Farrow, A., Larrea, C., Hyman, G., \& Lema, G. (2005). Exploring the spatial variation of food poverty in Ecuador. Food Policy, 30(5-6), 510-531.

Ferranti, P., Berry, E. M., \& Anderson, J. R. (2019). Encyclopedia of food security and sustainability. San Diego: Elsevier.

Ferreira, C. B., Araujo, J. A., Tabosa, F. J. S., \& Lima, J. R. F. (2016). Produtividade agrícola nos países da américa latina. Revista de Economia e Sociologia Rural, 54(3), 437-458. http:// dx.doi.org/10.1590/1234-56781806-94790540303

Food and Agriculture Organization of the United Nations - FAO. (1996). Rome Declaration on World Food Security. Rome: FAO.

Food and Agriculture Organization of the United Nations - FAO. (2002). Producción agrícola y seguridad alimentaria. In Food and Agriculture Organization of the United Nations (Org.), Agua y Cultivos, logrando el uso óptimo del agua en la agricultura. Rome: FAO.

Food and Agriculture Organization of the United Nations - FAO. (2011). The state of the world's land and water resources for food and agriculture (SOLAW) managing systems at risk. Rome: FAO.

Food and Agriculture Organization of the United Nations - FAO. (2017). FAOSTAT. Food Balances (old methodology and population). Retrieved in 2021, April 19, from http://www.fao.org/ faostat/en/\#data/FBSH

Food and Agriculture Organization of the United Nations - FAO. (2018a). The future of food and agriculture - alternative pathways to 2050. In Food and Agriculture Organization of the United Nations (Org.), IDS Bulletin. Retrieved in 2021, April 19, from http://www.fao.org/3/ 18429EN/i8429en.pdf

Food and Agriculture Organization of the United Nations - FAO. (2020a). Crops. Retrieved in 2021, April 19, from http://www.fao.org/faostat/es/\#data/QC

Food and Agriculture Organization of the United Nations - FAO. (2020b). Definitions and standards - New Food Balances. Retrieved in 2021, April 19, from http://www.fao.org/ faostat/en/\#data/FBS

Food and Agriculture Organization of the United Nations - FAO. (2020c). Deflactor. Retrieved in 2021, April 19, from http://www.fao.org/faostat/en/\#data/PD

Food and Agriculture Organization of the United Nations - FAO. (2020d). Detailed trade matrix. Retrieved in 2021, April 19, from http://www.fao.org/faostat/en/\#data/TM

Food and Agriculture Organization of the United Nations - FAO. (2020e). Land use. Retrieved in 2021, April 19, from http://www.fao.org/faostat/en/\#data/RL 
Food and Agriculture Organization of the United Nations - FAO. (2021). New Food Balances. Retrieved in 2021, April 19, from http://www.fao.org/faostat/en/\#data

Food and Agriculture Organization of the United Nations - FAO, Pan American Health Organization - OPS, World Food Programme - WFP, United Nations International Children's Emergency Fund - UNICEF . (2018b). Panorama de la seguridad alimentaria y nutricional en américa latina y el caribe, desigualdad y sistemas alimentarios. Retrieved in 2021, April 19, from http://www.fao.org/3/ca2127es/ca2127es.pdf

Giampietro, M., Aspinall, R. J., Ramos-Martin, J., \& Bukkens, S. G. (2014). Resource accounting for sustainability assessment: the nexus between energy, food, water and land use. London: Routledge.

Guinea, M. (2013). El modelo de seguridad alimentaria de la Unión Europea y su dimensión exterior. UNISCI Discussion Paper, 0(31), 20140403.

Hassan, R. M., Faki, H., \& Byerlee, D. (2000). The trade-off between economic efficiency and food self- sufficiency in using Sudan's irrigated land resources. Food Policy, 25(1), 35-54.

Hidalgo, C., \& Sorondo, L. (2020). Agroecología y soberanía alimentaria: ideas para el debate en camino a la agricultura sostenible. Revista de Ciencia y Tecnología Agrollanía, 19, 80-87.

Hix, S. (2001). Regional integration. In N. J. Smelser \& P. B. Baltes (Eds.), International Encyclopedia of the Social \& Behavioral Sciences. Amsterdam: Elsevier Pergamon. https://doi.org/https:// doi.org/10.1016/B0-08-043076-7/01274-2

Hochedez, C. (2021). Food justice: a conceptual framework and a category of action Perspectives from the Latin American context. Food Justice and Sovereignty in the Americas: Inequalities, Food and Agriculture, halshs-03017065.

Hossfeld, L. H., Kelly, E. B., \& Waity, J. F. (2018). Food and poverty: food insecurity and food sovereignty among America's poor. Nashville: Vanderbilt University Press.

Hubbard, M., Merlo, N., Maxwell, S., \& Caputo, E. (1992). Regional food security strategies. The case of IGADD in the Horn of Africa. Food Policy, 17, 7-22.

Kinnunen, P., Guillaume, J. H. A., Taka, M., D'Odorico, P., Siebert, S., Puma, M. J., Jalava, M., \& Kummu, M. (2020). Local food crop production can fulfil demand for less than one-third of the population. Nature Food, 1(4), 229-237. http://dx.doi.org/10.1038/s43016-020-0060-7

Koester, U. (1986). Regional cooperation to improve food security in Southern and Eastern African countries. Washington: International Food Policy Research Institute.

Krapohl, S. (2019). Games regional actors play: dependency, regionalism, and integration theory for the Global South. Journal of International Relations and Development, 23, 840-870. https://doi.org/10.1057/s41268-019-00178-4

Krugman, P., \& Obstfeld, M. (2003). International Economics: theory and policy (6th ed.). Hoboken: Pearson Education International.

Lall, S. (2000). Working paper number 44 the technological structure and performance of developing country. Oxford Development Studies, 28(3), 337-369.

Malinowski, B. (1939). El grupo y el individuo en análisis funcional. Revista Mexicana de Sociología, 1(3111-133), 111-133.

Malinowski, B. (1970). Una teoría científica de la cultura y otros ensayos. Buenos Aires: Editorial Sudamericana.

Maslow, A. H. A. H. (1943). A theory of human motivation. Psychological Review, 50(4), 370-396.

O'Hagan, J. P. (1976). National self-sufficiency in food. Food Policy, 1(5), 355-366. 
Organisation for Economic Co-operation and Development - OECD. Food and Agriculture Organization of the United Nations - FAO. (2019). OECDFAO Agricultural Outlook 20192028. Paris: OECD Publishing. https://doi.org/https://doi.org/10.1787/agr_outlook-2019-en

Pastorino, L. (2020). La seguridad alimentaria - un concepto pretencioso. Przegląd Prawa Rolnego, 2(27), 183-206. https://doi.org/https://doi.org/10.14746/ppr.2020.27.2.10

Pengue, W. (2009). Fundamentos de economía ecológica. Buenos Aires: Kaicron.

Prebish, R. (1950). The economic development of Latin America and its principal problems. New York: UN.

Prebish, R. (1959). American Economic Association Commercial Policy in the underdeveloped countries. The American Economic Review, 49(2), 251-273.

Ramos-Martín, J., Falconí, F., \& Cango, P. (2017). The concept of caloric unequal exchange and its relevance for food system analysis: the Ecuador case study. Sustainability, 9(11), http:// dx.doi.org/10.3390/su9112068

Rask, K. J., \& Rask, N. (2011). Economic development and food production-consumption balance: a growing global challenge. Food Policy, 36(2), 186-196.

Reis, L. D. R., Araújo, R. C. P., Araújo, J. A., \& Lima, J. R. F. de L. (2020). Eficiência técnica da produção agrícola dos países da América Latina e do Caribe. Revista de Economia e Sociologia Rural, 58(4), 1-15. http://dx.doi.org/10.1590/1806-9479.2020.219416

Rockström, J., Edenhofer, O., Gaertner, J., \& DeClerck, F. (2020). Planet-proofing the global food system. Nature Food, 1(1), 3-5. http://dx.doi.org/10.1038/s43016-019-0010-4

Samaniego, P., Vallejo, M. C., \& Martínez-Alier, J. (2017). Commercial and biophysical deficits in South America, 1990-2013. Ecological Economics, 133, 62-73. http://dx.doi.org/10.1016/j. ecolecon.2016.11.012

Schaffartzik, A., Mayer, A., Gingrich, S., Eisenmenger, N., Loy, C., \& Krausmann, F. (2014). The global metabolic transition: regional patterns and trends of global material flows, 1950-2010. Global Environmental Change, 26, 87-97.

Siegel, K. M., \& Bastos, M. G. (2020). When international sustainability frameworks encounter domestic politics: the sustainable development goals and agri-food governance in South America. World Development, 135, 105053. http://dx.doi.org/10.1016/J.WORLDDEV.2020.105053

Singer, H. W. (1950). The distribution of gains between investing and borrowing countries. The American Economic Review, 40(2), 473-485.

UNCTAD. (2019). Trade structure by partner, product or service-category. Retrieved in 2021, April 19, from https://unctadstat.unctad.org/EN/

Vallejo, M. C. (2010). Biophysical structure of the Ecuadorian economy, foreign trade, and policy implications. Ecological Economics, 70(2), 159-169. http://dx.doi.org/10.1016/j. ecolecon.2010.03.006

van Buuren, S., \& Groothuis-Oudshoorn, K. (2011). mice: Multivariate imputation by chained equations in R. Journal of Statistical Software, 45(3), 1-67. http://dx.doi.org/10.18637/jss.v045.i03

World Bank. (2021). World development indicators. Retrieved in 2021, April 19, from https:// data.worldbank.org/

Received: April 19, 2021

Accepted: October 19, 2021

JEL Classification: F15, 013, O54, Q17, Q18. 


\section{Supplementary Material}

Supplementary material accompanies this paper.

Table 5.1. Trade complementarity within Celac by product (thousands of tons) and country, 2018.

This material is available as part of the online article from https://www.scielo.br/j/resr 